\title{
ジョグジャカルタ・マリオボロＡSTUDY ON THE INSTITUTIONAL 通りにおける屋台マネジメント FRAMEWORK OF STREET の制度的枠組みに関する研究 VENDORS AT MALIOBORO STREET, YOGYAKARTA
}

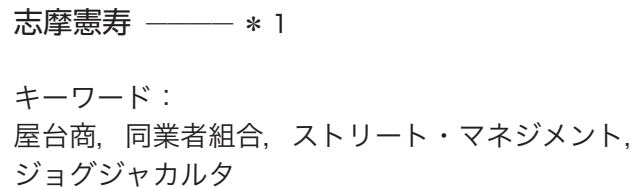

Keywords:

Street vendors, Association, Street management, Yogyakarta

\begin{abstract}
Norihisa SHIMA
How can livable street be created? This is a part of study to answer this question in terms of institutional framework. Through field survey of Malioboro Street, Yogyakarta, the paper aims to clarify the institutional framework for those street vendors running along Malioboro Street, with specific interest in the street vendor's associations called paguyuban. The conclusion highlights, under the recently altered mayor's decision, both the city government and the street vendors, which have organized the associations since the late 1980 's, are gradually preparing the institutional framework for collaborative as well as comprehensive street management of Malioboro Street.
\end{abstract}

\section{1.はじめに}

アジア諸都市のストリート空間には「屋台街」として、屋台が並び、 ストリート空間に賑わいを添えている例が多くみられるが、「インフ オーマル部門」によって担われることの多い屋台は、しばしば合理的 な空間利用を衫らう制度的枠組みの下ではストリート・マネジメン 卜上の軋轁ともなり得る。しかしながら、屋台業をはじめとするイン フォーマル部門は雇用の場として少なからぬ役割を果たしており、 また、近年はこうしたインフォーマル部門を再評価する向きもある。 今日、アジア諸都市において、とりわけ屋台の多いストリート空間で は、「屋台 vS 合理的なストリート・マネジメント」という二項対立 的 (かつ、行政主導型のトップダウン的なアプローチに終わることが 多い）構図を超えた共存の枠組みが求められることとなろう文1)。

本研究で扱うインドネシア・ジョグジャカルタ市のメインストリ 一トであるマリオボロ通りには数多くの屋台が出店しており、1980 年代より屋台商らによる同業者組合の組織化がみられたが、2009 年 には市文化・観光局下にマリオボロ通りの総合的マネジメントを担 う機関として「マリオボロ地区マネジメントユニット（UPT Kawasan Malioboro)」が設置され、また、2010 年にはマリオボロ 通りに出店寸る屋台に係る諸規定が市長令として定められる等、屋 台を活かしたストリート・マネジメントへの動きがみられる。

さて、アジア諸都市における屋台を扱った研究は多くみられるが、 それらを大別すると、例えば、バンコク、シンガポール、クアラルン プール、ホーチミンの屋台街の比較研究を行なった中村ら文2)をはじ めとして屋台の出店するストリートの空間的な特徴に着目したもの やManeepong ら文3)等の屋台商の経済的側面に着目したものが中心 であり、ストリート空間における屋台のマネジメントに焦点を当て たものは少ない。また、本研究に先立って著者らは、屋台商の置かれ た制度的枠組みや社会関係に着目しつつマリオボロ通りの屋台業と ストリート空間の利活用の実態を分析したが文4)、その背景にあるマ
リオボロ通りにおける屋台のマネジメントには深く言及していない。 しかしながら、「インフォーマル」という語からも想起されるように、 とりわけアジアの屋台のマネジメントにおいては、行政が主導する 「フォーマル」なマネジメントの枠組みの外側で、屋台商による（し ばしば「インフォーマル」と評される）自主的なマネジメントもまた 見られる（むしろ、それが卓越しているかもしれないが）と予想され る集1)。そこで、本研究では、行政による「フォーマル」なマネジメ ントの枠組みに加え、屋台商による「インフォーマル」または「自主 的」なマネジメントの枠組みを合わせた「制度的枠組み」に着目寸る こととしたい注2)。

このような問題意識に基づき、本研究は、ジョグジャカルタ市のマ リオボロ通りを事例として、関連法令や体制の整備等、屋台業をめぐ る行政の動向と屋台商らによる同業者組合「パグユバン」の活動をそ れぞれ俯瞰的に整理することによって、屋台をめぐるマネジメント の制度的枠組みを明らかにすることを目的としており、ストリート 空間の総合的マネジメントに向けた基礎的研究として位置付けたい なお、本研究は、ジョグジャカルタ市政府及び全ての同業者組合の代 表者等に対するインタビュー調查や関連資料の分析によって行った ものである注 3)。

\section{2. マリオボロ通りの屋台業を規定する法令}

本章では、まず基礎的情報としてジョグジャカルタ・マリオボロ通 りの屋台商の状況を概観した上で、行政による屋台業を規定する法 令や体制の整備等の状況を整理する。

\section{1 ジョグジャカルタ・マリオボロ通りの屋台商}

ジャワ島の中南部に位置するジョグジャカルタ市は、「ジャワの古 都」として知られ、バリに次ぐインドネシア第二の観光地である。市 の中心部には王宮「クラトン」や水の宮殿「タマン・サリ」等の歴史 的遺産やコタグデ地区等が観光名所として知られている他、2007 年 
には市政府肝入りのテーマパーク「タマン・ピンター」も開業した。 マリオボロ通りは注4)、市街地の北方 30 キロほどのムラピ山から南 方 20 キロほどのインド洋へと至る都市の軸線を成しており、ジョグ ジャカルタ駅から中央郵便局までの $1.2 \mathrm{~km}$ の区間には、州政府や議 会、ホテル、ショッピングモール、商店が並ぶ（図 1)

マリオボロ通りの沿道商店前のアーケード内や歩道には、商店側 とマリオボロ通り側の 2 列に並んで屋台が出店しており、著者らの 調查時にはマリオボロ通り全体で約 1,200 軒であった（図 2 の $\mathrm{A}$ 及 び B)。屋台の販売品は、衣料・服飾品や小物類、万うけつ染め「バ ティック」や手工芸品が多い。これらの屋台商は、「グロバック (gerobak、図 2 の) 」と呼ばれる荷車に販売品を詰め、荷をほど いて店舗として使用している。飲食業を営む屋台は、ブリンハルジョ 市場付近を中心に出店しており、青果物やペットボトル飲料、スナッ ク菓子等を販売する者の他、「アンクリンガン（ankringan、図 2 の D)」と呼ばれる形態の屋台がみられ、また、夕方から夜間にかけて は、歩道に䈻とテントを設置した「レセハン（lesehan、図 2 の E)」 と呼ばれる屋台が出店し、各種インドネシア料理や提供している注5)。 2.2 マリオボロ通りの屋台業に関する基本法と行政の動向

マリオボロ通りに出店する屋台に関する諸規定を定めた基本法は、

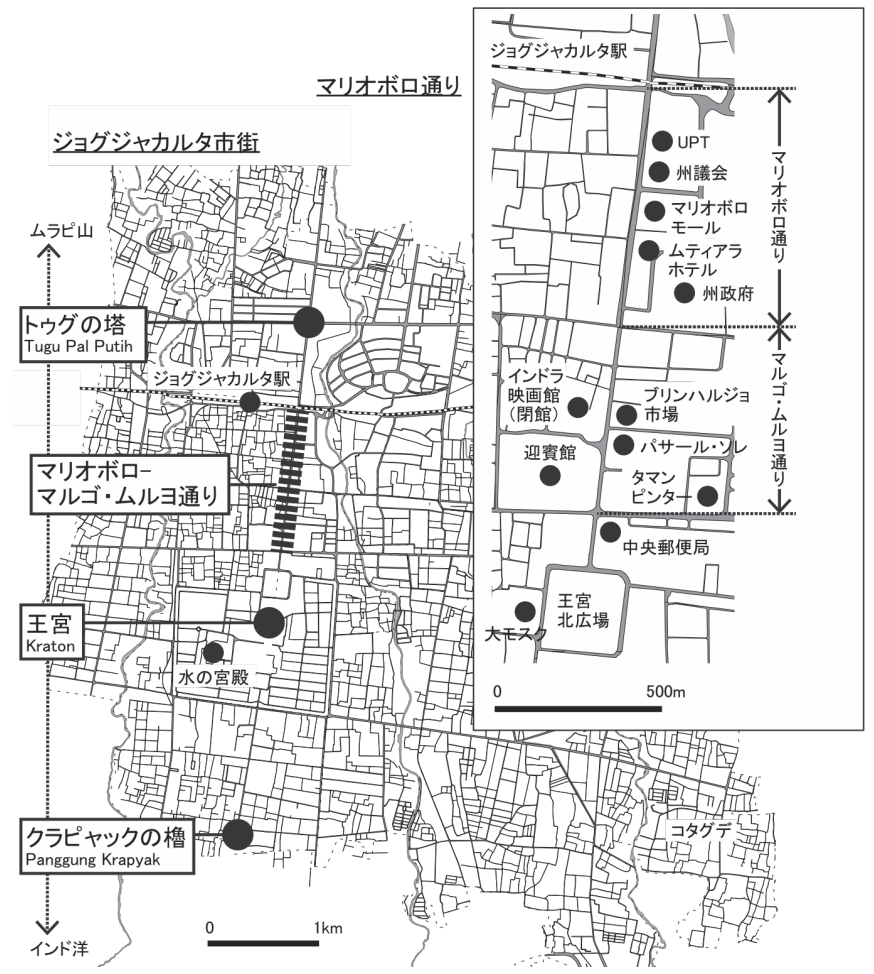

図 1 ジョグジャカルタ市中心部とマリオボロ通り（マリオボローマ ルゴ・ムルヨ通り)
「マリオボロ-A・ヤニ通り地区の屋台業に関するジョグジャカルタ 市長令 2010 年第 37 号（以下「市長令」）」である注6)、注7)。同市長 令には、マリオボロ通りからマルゴ・ムルヨ通りにおいて、屋台商の 出店可能な場所や業種、営業時間、屋台の大きさ、出店手続き、各種 の遵守事項等が示されており注8)、出店可能な場所等は主要な施設や 街路を区切りとして、アーケードや歩道の西側・東側に分けて規定さ れている(図 3) 注9)。

屋台のマネジメントを担う行政（市役所）側の体制として、市長令 の運用をはじめとするマリオボロ通りの総合的なマネジメントを担 うUPT があるが、UPT は、マリオボロ通り地区における、観光振 興、環境維持、インフラ維持、治安維持、商業、交通管理等に係る事 項を扱うこととされ、職員は市長令の運用状況を巡視したり、夜警も 行っている。また、屋台商や沿道商店主らによる同業者組合「パグユ バン（paguyuban）」や地元の代表者を交えた月例の会合等を通した 情報交換を図っており、この定例会への出席が求められているパグ ユバンは第 3 章で扱う 24 団体である。なお、屋台の出店は、最終的 には市が許可証を発行する形で許可されるが、まずは出店箇所を所 管するパグユバンと地元の承認を得る必要がある注１0)。

\section{3. 同業者組合「パグユバン」とその活動}

次に、同業者組合「パグユバン」 24 団体の設立状況、団体規模、 活動の内容、設立の時期・経緯を中心に見てゆきたい（表 1) 注 11 ）。 3.1 設立状況

このうち、連合会的な活動を行うものは、全てのパグユバンのまと

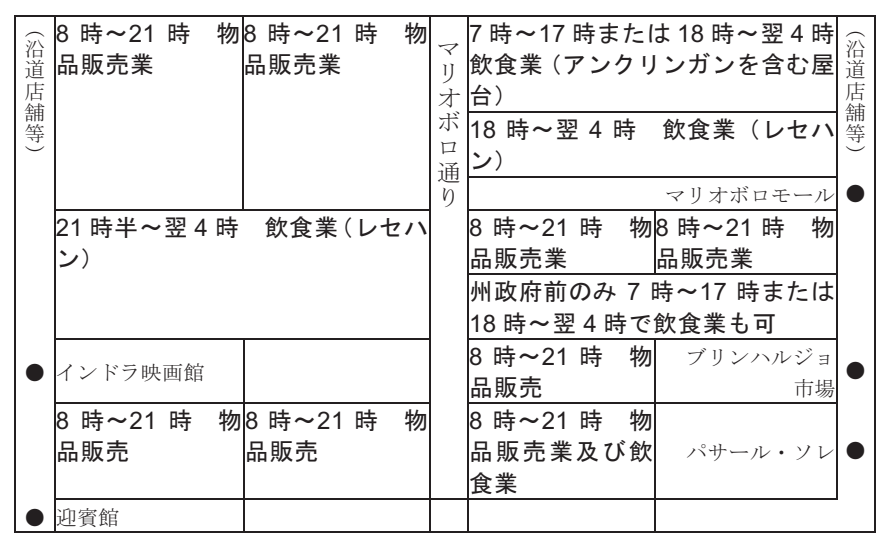

*1 なお、アーケードや歩道の沿道店舗側とマリオボロ通り側とで営業時間は 同じであるが、出店可能な屋台の大きさには違いがある。例えば、沿道店舗 側では、店舗の柱からはみ出してよい範囲や店舗の出入口を塞がない等の規 定が定められている。

*2 市長令にはこの他にもマリオボロ通りより東西方向に伸びる 3 本の街路 (Pajeksan、Reksabayan、Suryatmajan 各通り)にも同様の規定がある。

図 3 市長令に定められた屋台の出店可能な場所と業種、営業時間 (出典：市長令より筆者作成)

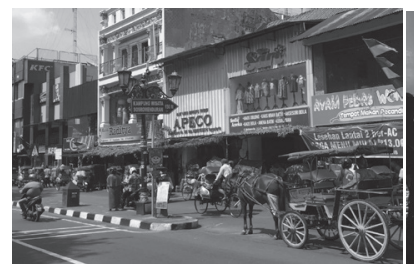

A : 沿道商店とアーケード 図 2 マリオボロ通りの屋台

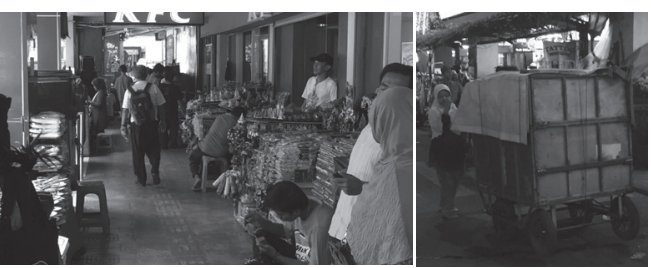

$\mathrm{B}:$ アーケード内の屋台

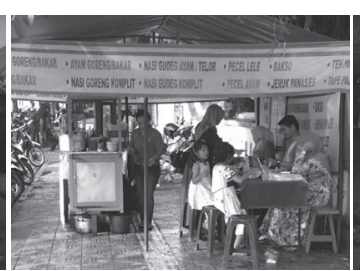

C : グロバック D : アンクリンガン

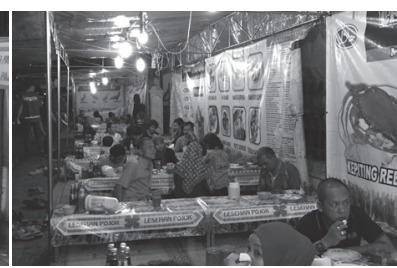

$E ：$ レハン 
表 1 同業者組合「パグュバン」とその活動（出典：インタビュー調査等より作成）

\begin{tabular}{|c|c|c|c|c|c|c|c|}
\hline \multicolumn{4}{|c|}{ パグュバン } & 組合員数 ${ }^{2}$ & $\begin{array}{l}\text { 組合費”2 } \\
\text { (ルピア) }\end{array}$ & 主な活動 & 設立年 ${ }^{2}$ \\
\hline \multirow{3}{*}{$\begin{array}{l}\text { 連 } \\
\text { 会 } \\
\text { 活 } \\
\text { 的 } \\
\text { 動 }\end{array}$} & \multicolumn{3}{|c|}{ LPKKM } & $\begin{array}{l}\text { パグユバン } \\
\text { 代表者 }\end{array}$ & $\begin{array}{l}\text { 必要に } \\
\text { 応じて }\end{array}$ & 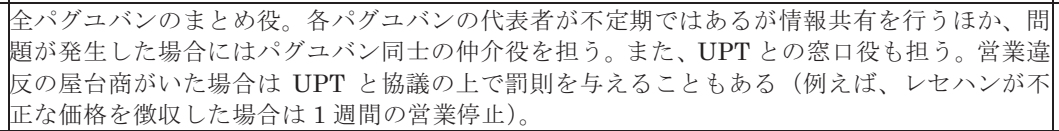 & 2009 年 \\
\hline & \multicolumn{3}{|c|}{ Moral } & \begin{tabular}{|l|l|} 
約 150 名 \\
パグュバン有志
\end{tabular} & $\begin{array}{l}\text { 必要に } \\
\text { 応じて }\end{array}$ & $\begin{array}{l}\text { マリオボロ通りの治安維持や救護活動等を自主的に行い、通りのイメージ向上や安全性向上を } \\
\text { 放らう。各パグユバンからの有志によって設立・運営されてい。 }\end{array}$ & 2013 年 \\
\hline & \multicolumn{3}{|c|}{ PIIKM } & $\begin{array}{l}\text { パグユバン } \\
\text { 代表者 }\end{array}$ & 1 万/月 & $\begin{array}{l}\text { 頼母子講（アリサン）のまとめ役。各パグユバンの代表者による活動で、組合費のうち } 3,000 \\
\text { ルピアを組織運営、7,000 ルピアを積立に充てる。貧しい子供達への食事の提供も。 }\end{array}$ & 2003 年 \\
\hline & \multirow{6}{*}{\multicolumn{2}{|c|}{ 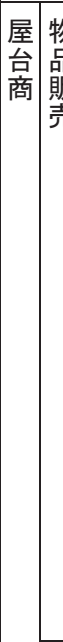 }} & Tri Dharma & 約 850 名 & 3 万 $/$ 月 & 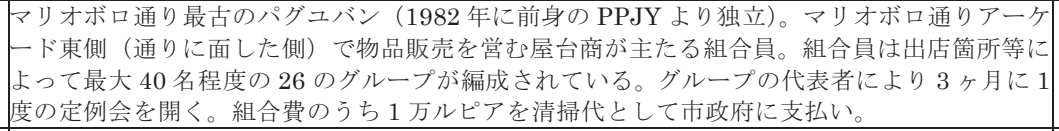 & 1982 年 \\
\hline & & & Pemalni & 約 380 名 & 1 万/月 & $\begin{array}{l}\text { マリオボロ通りアーケード西側（沿道店舗に面した側）で物品販売を営む屋台商による組合。 } \\
\text { 組合員数は約 } 380 \text { 名。Tri Dharma 同様に } 0 \text { のグループが編成され、グループの代表者によ } \\
\text { り } 2 \text { 週間に } 1 \text { 度の定例会を開く。組合には清掃代を含み、ぞの } 50 \% \text { は積み立てる。組合員は } \\
\text { 金利 } 1 \% \text { 借入も可能。正規営業権獲得のため設立。 }\end{array}$ & 1992 年 \\
\hline & & & Tri Manunggal & & $\begin{array}{l}10 \text { 万 } / \text { 月 } \\
\text { (組合全体) }\end{array}$ & 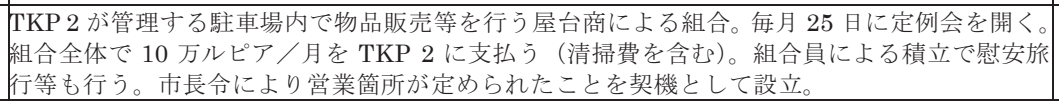 & 2004 年 \\
\hline & & & Pasar Senthir & & 1.5 万／月 & 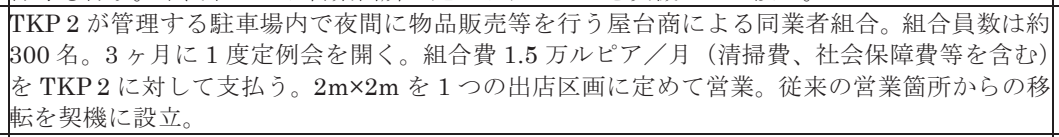 & 2003 年 \\
\hline & & & Pasar Sore & 45 名 & $\begin{array}{l}1 \text { 万／月 } \\
+ \text { 清掃費 }\end{array}$ & 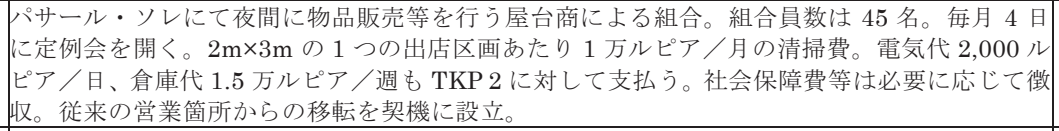 & 2003 年 \\
\hline & & & PAMARTA & & & 流しでのタバコ販売者による組合。あまり活動は見られず、UPT の定例会への出席もない。 & \\
\hline & & $\begin{array}{l}\text { 飲 } \\
\text { 食 } \\
\text { 業 }\end{array}$ & Handayani & 約 60 名 & $\begin{array}{l}1 \text { 万/月 } \\
+ \text { 清掃費 }\end{array}$ & 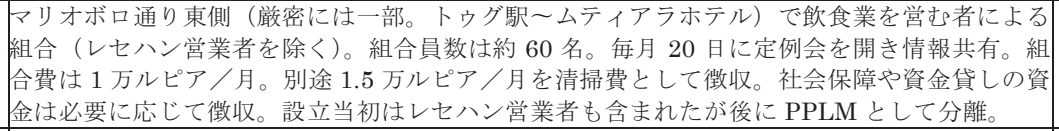 & 1993 年 \\
\hline & & & Padma & & $\begin{array}{c}5,000 / \text { 月 } \\
+ \text { 清掃費 }\end{array}$ & 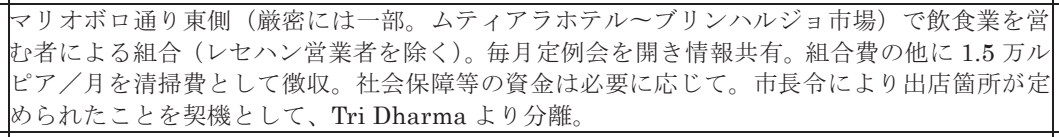 & 2004 年 \\
\hline & & & PPLM & 52 名 & 50 万／月 & $\begin{array}{l}\text { マリオボロ通り東側のレセハン営業者の組合。組合員数は } 52 \text { 名。不定期ではあるが会合を開 } \\
\text { く。組合費は } 50 \text { 万ルピアノ/月のうち清掃代は } 1.5 \text { 万ルピア。また、断食明けや独立記念日等の } \\
\text { 煂にには } 15 \text { 万ルピアを徵収。 }\end{array}$ & 2000 年 \\
\hline & & & PPKLY-37 & & $\begin{array}{c}3000 / \text { 月 } \\
+ \text { 清掃費等 }\end{array}$ & $\begin{array}{l}\text { パサール・ソレ前で飲食業等を営む者による組合。繁忙期には毎月定例会（閑散期は } 2 \text { ケ月 } \\
1 \text { 回)。組合費の他に清掃 } 1.5 \text { 万ルピア／月。また、電気代として } 2.5 \text { 万ルピア／日を皆で支 } \\
\text { 払う。同業者間の情報交換を主たる目的として } 1991 \text { 年に設立。 }\end{array}$ & 1991 年 \\
\hline & & & PAPELA & 98 名 & $\begin{array}{c}\text { 万 万/月 } \\
+ \text { +清掃費等 }\end{array}$ & 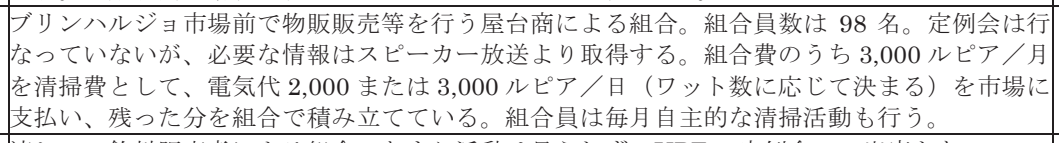 & \\
\hline & & & PAMAYA & & & 流しでの飲料販売者による組合。あまり活動は見られず、UPT の定例会への出席もない。 & \\
\hline & & & $\begin{array}{ll}\text { PASMAL } \\
\text { Setangah Jam }\end{array}$ & & & $\begin{array}{l}\text { いずれも流しの営業者による組合。PASMAL はストリートミュージシャン、Setangah Jam は } \\
\text { 画家。あまり活動は見られす、UPT の定例会への出席もない。 }\end{array}$ & \\
\hline & \multirow{2}{*}{\multicolumn{2}{|c|}{ 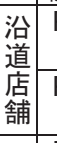 }} & & & $\begin{array}{l}1 \text { 万/月 } \\
+ \text { 清掃費 }\end{array}$ & $\begin{array}{l}\text { マリオボロ通り沿道の店舗主による組合。会合は開かず書面での情報共有が中心。組合費 } 1 \text { 万 } \\
\text { ルピアノ/を社会保障費等に充てる。清掃費 } 1.5 \text { 万円/月は各店舗が市政府に直接支払う。 }\end{array}$ & 1995 年 \\
\hline & & & & 45 名 & 清掃費 & $\begin{array}{l}\text { 巾ニ通り（現：マルゴ・ムルヨ通り）沿道の店舗主による組合。会合は開かず書面での情報共 } \\
\text { 有が中心。組合費は定めておらず、清拂費は個別に支払う。社会保障費等は必要に応じて。。 }\end{array}$ & 2004 年 \\
\hline & \multirow{5}{*}{$\begin{array}{l}\text { 交 } \\
\text { 通 } \\
\text { サ } \\
\text { l } \\
\text { ビ } \\
\text { ス }\end{array}$} & \multicolumn{2}{|c|}{ PAY } & $\begin{array}{c}40 \text { 名 } \\
\text { 市内全域で } \\
635 \text { 名 } \\
\end{array}$ & $\begin{array}{l}\text { 必要に } \\
\text { 応じて }\end{array}$ & 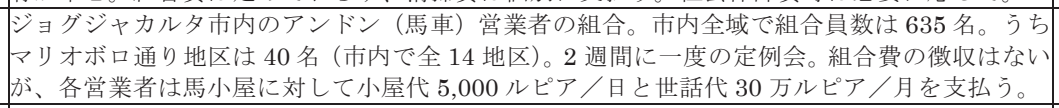 & \\
\hline & & \multicolumn{2}{|c|}{ PBM } & $\begin{array}{l}\text { 市内で } \\
\text { 約 } 6,000 \text { 名 }\end{array}$ & 1 万／月 & 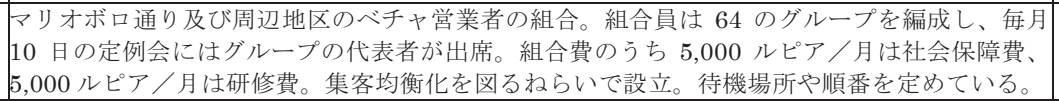 & 2005 年 \\
\hline & & \multicolumn{2}{|c|}{ TKP 1} & 145 名 & $5,000 /$ 月 & $\begin{array}{l}\text { トゥグ駅付近にある駐車場を管理する組合。組合員は全 } 145 \text { 名（うち駐車場整理員等 } 21 \text { 名、 } \\
\text { 物品販売等を営む屋台商 } 102 \text { 名、ベチャ運転手 } 22 \text { 名)。毎月 } 1 \text { 日に定例会。市交通とも定例 } \\
\text { 的に会合を絲く。開合費には清掃費を含まない。社会保障や貸付資金は組合員の付によ。 }\end{array}$ & \\
\hline & & \multicolumn{2}{|c|}{ TKP 2} & $\begin{array}{l}\text { パグユバン } \\
\text { 代表者 }\end{array}$ & \begin{tabular}{|c|c|} 
パグユバン毎 \\
に異なる
\end{tabular} & $\begin{array}{l}\text { パサール・ソレの駐車場を管理する組合。Tri Manunggal、Pasar Senthir、Pasar Sore を統括 } \\
\text { し、毎月 } 20 \text { 日の定例会にはハハグユ゙゙ンの代表者が出席。組合費は各パグュバンを通じて徵収。 }\end{array}$ & 2012 年 \\
\hline & & \multicolumn{2}{|c|}{ PPMAY } & 200 名超 & 1,000/月 & $\begin{array}{l}\text { マリオボロ通りのバイク駐車場を管理する組合。組合員数は } 200 \text { 名を超える。毎月 } 15 \text { 日に定 } \\
\text { 例会。組合費はヘルメット紛失等の駐車場利用者の事故対応にも充てる。 }\end{array}$ & 2001 年 \\
\hline
\end{tabular}

*1 パグユバン略称 : LPKKM (Lembaga Pemberdayaan Komunitas Kawasan Malioboro), PPM (Paguyuban Pengusaha Malioboro), PPAY (Paguyuban Pengusaha Ahmad Yani), PAY (Paguyuban Andong Yogyakarta), PBM (Paguyuban Becak Malioboro), PPLM (Paguyuban Pedangan Lesehan Malioboro), PPMAY (Paguyuban Petugas Parkir Maliobolo - Ahmad Yani), TKP (Taman Khusus Parkir), PPLM (Paguyuban Pedagang Lesehan Malioboro), PPKLY (Paguyuban Pedagang Kaki Lima Yogyakarta), PAPELA (Paguyuban Pedagang Lepak), PASMAL (Paguyuban Seni Musik Lesehan Malioboro), PAMAYA (Paguyuban Asongan Yogyakarta)

*2 空欄は不明または回答なし。組合費は定期的なものに限り必要に応じて徴収するものは記載していない。 
め役である「マリオボロ地区コミュニティエンパワメント協会 $(\mathrm{LPKKM}) 」 の$ 他、自主的な治安維持や救護活動等を行う Moral、 頼母子講（アリサン）のまとめ役である PIIKM がある。いずれもパ グユバンの代表者によって構成されているが、中でも Moral ではパ グユバンの有志によって設立・運営されている点で興味深い。

また、同業者による組合も業種や出店箇所によって様々に設立さ れており、業種別にみると、まず、屋台商によるものとして、物販販 売 6 団体、飲食業 6 団体、その他のサービス業で（これらはあまり 活発には活動していないようではあるが） 2 団体がある。また、マリ オボロ通り、マルゴ・ムルヨ通りの沿道商店主による同業者組合もそ れぞれ組織されている。さらに、交通サービスを提供する同業者によ る組合も 5 団体ある。

\section{2 団体規模（組合員数・組合費）}

これらの同業者組合の組合員数は、屋台業の業種構成を概ね反映 しており、物品販売業者による Tri Dharma や Pemalni 等は数百人 規模に上るが、同業者数の増加に伴い、PPLM のように前身団体か ら独立して新たな組合が設立されることもある。

定期的に徵収される組合費は業種毎の利益を一定程度反映してい ると思われる。例えば、客単価も高いレセハン(飲食業) 組合の PPLM では 1 ケ月当たりの組合費は 50 万ルピアであるのに対して、バイク 駐車場管理員組合 PPMAY では 1,000 ルピアであるし注 12 2)、また、 同じ物品販売の屋台商でも出店籄所の広いマリオボロ通りアーケー ド東側（Tri Dharma）では、組合費が 3 万ルピア／月であるのに対 し、西側の沿道店舗前を利用した出店区画の狭い屋台商の組合 (Pemalni) では 1 万ルピア／月である。なお、物品販売や飲食業を はじめとしてマリオボロ通りを利用する業態では組合員は組合を通 じて清掃費も支払っており（他方、例えば、PAY のように交通サー ビス系では事業者が個別にサービスに対して支払いがある)、パサー ル・ソレやブリンハルジョ市場、駐車場をはじめとする場所を借りて 営業している場合には電気代や場所代等の支払いもある（例えば、 PPKLY-37、PAPELA、Tri Manunggal、Pasar Senthir、Pasar Sore 等)。また、PPLM のように断食明けや独立記念日等の慶事に積立を 行う例もあり、組合員の親睦旅行等の費用に充てることが多い。

\section{3 主な活動}

同業者組合であることから活動の中心は、定例会等を通じた情報 共有や傷病時の保険、事故対応等の社会保障、(例えば Pemalni にみ られるように比較的低利での）事業資金等の貸付をはじめとした組 合員間の互助を目的としたものである。例えば、駐車場を利用した物 販販売業の Pasar Senthir や Pasar Sore では、組合によってそれぞ れ $2 \mathrm{~m} \times 2 \mathrm{~m} 、 2 \mathrm{~m} \times 3 \mathrm{~m}$ の出店区画が定められているし、ベチャ営業 者による組合 PBM では組合が待機場所や順番を定めることによっ て集客の均衡化を図っている。

\section{4 設立の時期・経緯}

これらの同業者組合が設立された時期や経緯を概観すると、もつ とも古い Tri Dharma は 1981 年に設立され注13)、1990 年代には Pemalni や Handayani、PPKLY-37 等、さらに 2000 年代に入ると 殆どの組合が設立されている。設立の経緯は、前述のような同業者数 の増加もさることながら（Tri Dharma もその例であるという）、Tri Manunggal や Pasar Senthir、Pasar Sore、Padma のように、前述 の市長令等に出店箇所が明記されたことを契機として設立されたも
のも多(注 14$)$ 。また、Pemalni のように正規の営業許可を取得する ために設立されたものもある。さらに、2000 年代に入ると、典型的 には LPKKM であるが、この他にも PIIKM や TKP 2 のような「ま とめ役」を担う組織化が進んでいることも特筆に值しよう。

\section{4. まとめ}

マリオボロ通りの屋台商をめぐっては、「マリオボローA・ヤニ通り 地区の屋台業に関するジョグジャカルタ市長令 2010 年第 37 号」の 改変によって制度的枠組みが整えられつつある中で、マネジメント 体制をみると、行政側では市の文化・観光局内に「マリオボロ地区マ ネジメントユニット (UPT)」が設置された。その一方、屋台商や沿 道商店主といった事業者側では、（当初は政治的な背景も見えがくれ は寸るものの) 1980 年代以降、互助的な活動を中心とした様々な規 模の同業者組合「パグユバン」が設立または再編され、さらに、とり わけ 2000 年代以降は「マリオボロ地区コミュニティエンパワメント 協会 (LPKKM)」に代表されるような、まとめ役を担う組織も作ら れるようになっていた。このようなマリオボロ通りの屋台のマネジ メントの状況をみると、行政側・事業者側の両者がストリート・マネ ジメントに向かう制度的枠組みが (少なくとも形式としては) 構築さ れたということになろう。

最後に、マリオボロ通りの限られた事例からではあるが、屋台とス トリート・マネジメントとの共存に向けた論点を素描しておきたい。 まず第一に、「インフォーマル部門」として社会経済的に弱い立場に 置かれた屋台商による相互扶助活動の母体として同業者組合パグユ バンが設立され、さらに、市政府（とりわけストリート・マネジメン トを担うUPT）との空口役として、これら同業者組合の連合会とし て LPKKM 等もまた設立されていることによって、屋台商の社会経 済的なエンパワーメントが図られ、かつ、UPT や市長令をはじめと するトップダウン的なアプローチのみに押し切られることなくボト ムアップ的なアプローチを推める母体となり得よう。とりわけマリ オボロ通りの場合、市政府側のUPT が（ともすると合理性を優先し がちな交通や経済に係る部局ではなく) 文化・観光局の下に設置され ていることは、マリオボロ通りというストリートを文化として据え ようとする市の姿勢の現れであるとも考えられ、「合理的なストリー ト・マネジメント」のみに留まらない豊かな展開が期待できよう。

それでは、このようなストリート・マネジメントの制度的枠組みの 下、マリオボロ通りの空間的な賑わいはどのように創出されている のだろうか。続く研究課題としたい。

謝辞 本研究のデータ収集等に多大なる尽力を頂いた保住麻貴氏と相津七海 氏（東洋大学国際地域学部卒業生）、また、ガジャマダ大学建築学科 Muhammad Sani Roychansyah 先生をはじめ現地調查に御協力頂いた皆様 にここに改めて謝意を表する。なお、本研究は JSPS 科研費 JP2 2249085 及 びJP26820258 の助成を受けて実施した。

注

（1）例えば、相津ら（2016）では、隣り合う屋台商等が互いに相談しあいなが ら、規定には定められていない箇所で屋台を出店させている例が報告され ている。

（2）したがって、本研究の制度的枠組みとは英語で言う「institution」に近い ものであり、ダグラス・ノース等の制度学から着想を得ている（文献 4)。

（3）インタビュー調査は 2015 年 8 月から 11 月にかけて実施し、その後もメー ルやインターネット等でフォローアップした。

（4）厳密には州政府南方からは「マルゴ・ムルヨ通り」（旧 A・ヤニ通り）と呼 ばれるが、本研究では特に区別しなくとも差し支えはない。 
（5）具体的な業種構成や出店数は文献 1 に詳しい。

（6）なお、同市長令は市長令 2002 年第 26 号及びその施行令 2007 年第 45 条 を改変したものであり、最初のものは市長令 1987 年第 56 号である。

（7）なお、同市長令は道路法や環境保護・管理法等に即して策定されている。

（8）市長令に違反した場合は 3 ケ月未満の懲役または 200 万ルピアの罰金が課 せられる。

（9）具体的な屋台の出店空間等は文献 1 に詳しい。

(10) ここで言う地元とは「クチャマタン（kecamatan、郡）」「クルラハン (kelurahan、町)」を指寸。インドネシアの地方行政では、市の下にクチ ヤマタン、その下にクルラハンが置かれており（但し、農村部等はこれと 異なる)、クチャマタンとクルラハンは自治権を有さず市の事務を担う。 なお、マリオボロ通り西側と東側とでは郡も町も異なっており、インタビ ユー調査では、このような行政上の分断状況を解消して風通しを良くす ることも同業者組合設立の契機としてあげられた。

(11) 東西方向街路の屋台でも同業者組合に近い活動を行なってはいるが、そ の活動は不定期なものに留まったり、町内会（RT : Rukun Tetangga）や 隣組（RW : Rukun Warga）が実質的な組合に近い活動を行なっている場 合もある。

（12）管理員はバイク駐車場のチケットを販売しており（1,000 ルピア／回）、 販売額の $25 \%$ は 100 枚単位で市税として徴収されている。

（13）なお、Tri Dharmaの前身である PPJY (Paguyuban Pedagang Pinggir Jalan Yogyakarta）は、当時のスハルト政権下の与党ゴルカル所属する市 議会議員らによる屋台商の教育・保護団体 KOSGORO から派生して設立 されたものである。

（14）この背景には、かつて屋台が多く並んでいた箇所にタマン・ピンターの建 設が始まったことも見えがくれしている。

\section{参考文献}

1）相津七海・志摩憲寿: ジョグジャカルタ・マリオボロ通りにおける屋台商の 営業実態とストリート空間の利活用に関寸る研究、都市計画論文集、Vol.51 No.3、pp.1197-1206、2016

2）中村航・古谷誠章：東南アジア 4 年の屋台街における屋台の様態と自生す る秩序の関係、日本建築学会計画系論文集、第 76 巻 第 661 号、pp.583-591、 2011

3) Maneepong, C. and Walsh, J. C.: A new generation of Bangkok street vendors, Cities, Vol.34, pp.37-43, 2013

4）ダグラス・C・ノース (著)、㴰澤弘和、中林真幸（訳）：ダグラス・ノース 制度原論、東洋経済出版社、2016

[2018 年 2 月 7 日原稿受理 2018 年 4 月 11 日採用決定］ 